\title{
A Study of Style: Stylistics in Two Poems of Seribu Sajak Tao Toba as Teaching Material on Poetry Appreciation Course
}

\author{
Mhd. Anggie Januarsyah Daulay \\ \{anggie.fbsunimed@yahoo.com\} \\ Literature Study Program, Universitas Negeri Medan, Indonesian
}

\begin{abstract}
This research aims to reveal how the style description of the text structure in the two poems of North Sumatera Poet compiled in the Anthology of Poetry book Seribu Sajak Tao Toba. The research indicators used were guided by four aspects of style based on literary stylistics study including a) diction, b) rhyme, c) imagery, and d) figurative language. The achievement of this research analysis applied the descriptive qualitative method. The results of the study were concluded as follows, 1) In the poem Seribu Sajak Tao Toba was found denotation and connotation diction, clerihew rhyme and alliteration rhyme, visual imagery, feeling, auditory, olfactory, and motion imagery, whereas in figurative language was found hyperbole, personification, sarcasm, allegory, and antanaclasis. 2) In Berita dari Kaldera Toba Purba poem was discovered connotation and denotation diction, monorhyme, feeling, olfactory, visual and motion imagery, while in the figurative language, hyperbole, allegory, personification, sarcasm, satire, rhetoric, cynicism, and association were found. The external target achieved is textbooks with ISBN, scientific publications in the national journal, international seminar proceedings, and the integration of the research result in the semester learning plan (RPS) of Poetry Appreciation course.
\end{abstract}

Keywords: Literary Stylistics, two poems of North Sumatera Poet.

\section{Introduction}

A literary work especially poetry is inseparable from the presence of a poet as the center of feelings, thoughts, and meanings. Every poet has different feelings, thoughts, and meaning, this is one of the characteristics of the poetic style of a writer. Various efforts can be made to approach and find out the peculiarities of these poetic styles. An effort that can be done is through a comprehensive assessment of the literary text. The analytical study that can be used is the Literary Stylistic approach. The literary perspective sees Stylistics as a study that investigates the linguistic style of writers through their work. Poetry has a limited medium that only consists of a few lines of sentences, but must be able to convey a message, as well as short stories and even novels that consist of several pages [1]. Some of North Sumatra writers whose poetry will be analyzed are Perahu Kecil di Atas Danau by Nestor Rico Tambunan and Berita dari Kaldera Toba Purba by Tri Budhi Sastrio. The two poems written by several poets above are included in the Anthology of Poetry book Seribu Sajak Tao Toba.

Based on the description above, the problem of this study is how the style of the poet in the text structure of the two poems, in terms of Stylistics aspects of poetry literature, namely: a) diction; b) rhyme; c) imagery; and d) figurative language. The objectives of this research 
are to describe the diction, rhyme, imagery, and figurative language. Theoretically, this study can enrich literary theories, especially in the fields of teaching literary theory, literary criticism, and literary analysis. The practical benefit of this study can become a library in further research by researchers, especially the researchers themselves and students of analytical study using Literary Stylistics study.

\section{Literature Review}

Poetry as an aesthetic work is a form of written expression that contains the ideas, thoughts, feelings, experiences, and observations of poets in the unity of form and creation that is complete and free. The unity of forms in poetry can be in the form of sense, feeling, imagination, tone, and intention.

The study of stylistics as one of poetry analysis has several aspects of the study, aspects of the study aimed to find out the characteristics of a poet in his work. There are seven indicators in studying poetry based on a stylistics perspective, namely a) diction, b) tone, c) rhyme, d) rhythm, e) intonation, f) imagery and g) figurative language [2]. However, the indicators used in this study are only in a) diction, b) rhyme, c) imagery, and d) figurative language. Stylistics has broad benefits including, a) Identifying and finding facts from each aesthetic literary work, b) Identifying broad characteristics of each writer that can be seen clearly on differences in their works, c) Being a source of knowledge of language differences, style dynamics, and imaginary explosion of a writer, d) In the study process, it becomes a separate value from reviewers about the wild activities of writers which include psychosis fluctuations and forms of taste, e) Expressing to mass in the form of literary papers about wellarranged correlations between the use of language in literary works, f) Helping the literature field to immediately fix the problematics of the work by improving the better quality, g) Making a harmonious relationship between reviewers with further study activities [2].

\section{Research Method}

The method used in this research was a descriptive method by describing the data through the analysis of the poetry style of seven North Sumatra poets in the study of Literary Stylistics. Through the descriptive method, the research results obtained through the process of identifying and analyzing data were objectively described. The data of the research were taken from the anthology of poetry book Seribu Sajak Tao Toba. The two poems as the source of data, namely Perahu Kecil di Atas Danau by Nestor Rico Tambunan and Berita dari Kaldera Toba Purba by Tri Budhi Sastrio, were taken from the Anthology of Poetry book Seribu Sajak Tao Toba.

The method of data collection chosen was the listening method. The listening method is a method used in language research by listening to the use of language on the object under study [3]. The steps of the listening method used were 1) listening intensively and repeatedly; 2) selecting data; 3 ) recording the relevant data; 4) conducting data analysis based on the theory used; 5) compiling a research report. 


\section{Result and Discussion}

4.1 Result of the Study

4.1.1 A poem Perahu Kecil di Atas Danau by Nestor Rico Tambunan

Table 1. Diction

\begin{tabular}{|c|c|c|}
\hline No & Denotation Diction & Connotation Diction \\
\hline 1 & $\begin{array}{l}\text { aku menatapmu pagi itu, terayun ayun } \\
\text { di atas perahu kecil. } \\
\text { menjala pora pora }\end{array}$ & $\begin{array}{l}\text { cahayanya bagai perak yang beriak-riak } \\
\text { bagai riak gelora gadis cantik } \\
\text { tubir kaldera berdiri penuh misteri }\end{array}$ \\
\hline 3 & $\begin{array}{l}\text { Anak-anak muda telah pergi } \\
\text { Menuju rantau yang penuh mimpi } \\
\text { Karena danau tak lagi bisamemberi } \\
\text { Mereka pergi jauh, dan jarang mau } \\
\text { kembali } \\
\text { Kalaupun kembali pasti lama sekali } \\
\text { Itupun sekali-sekali } \\
\text { Mungkin karena orang tuanya mati }\end{array}$ & $\begin{array}{l}\text { banyak yang telah berubah } \\
\text { Air danau tak lagi jernih dan mewangi } \\
\text { Karena keramba dan limbah mencemari } \\
\text { Penuh tumpukkan sampah yang menari- } \\
\text { nari } \\
\text { Di atas sana, gunung kehilangan pohon- } \\
\text { pohon }\end{array}$ \\
\hline
\end{tabular}

Table 2. Rhyme

\begin{tabular}{cll}
\hline No & \multicolumn{1}{c}{ Clerihew Rhyme } & Alliteration Rhyme \\
\hline 1 & $\begin{array}{l}\text { Di usiamu yang makin renta } \\
\text { mungkin teman, tanpa kekasih tercinta } \\
\text { kau tetap setia menjala pora-pora } \\
\text { karena kau tak mau berjudi } \\
\text { mencari hidup yang tak kau pahami } \\
\text { Bahwa hidup tak melulu soal materi }\end{array}$ & $\begin{array}{l}\text { Menjala pora-pora } \\
\text { di antara riak dan kaldera }\end{array}$ \\
\hline
\end{tabular}

Table 3. Imagery

\begin{tabular}{|c|c|c|c|c|c|}
\hline No & $\begin{array}{c}\text { Visual } \\
\text { Imagery }\end{array}$ & $\begin{array}{l}\text { Feeling } \\
\text { Imagery }\end{array}$ & $\begin{array}{l}\text { Auditory } \\
\text { Imagery }\end{array}$ & $\begin{array}{l}\text { Olfactory } \\
\text { Imagery }\end{array}$ & Motion Imagery \\
\hline 1 & $\begin{array}{l}\text { Aku } \\
\text { menatapmu } \\
\text { pagi itu }\end{array}$ & $\begin{array}{l}\text { Bagai } \\
\text { benteng } \\
\text { purba } \\
\text { menahan } \\
\text { luka }\end{array}$ & $\begin{array}{l}\text { di antara } \\
\text { riak dan } \\
\text { kaldera }\end{array}$ & $\begin{array}{l}\text { air danau tak } \\
\text { lagi jernih dan } \\
\text { mewangi }\end{array}$ & $\begin{array}{l}\text { Penuh tumpukan } \\
\text { sampah yang } \\
\text { menari-nari }\end{array}$ \\
\hline 2 & $\begin{array}{l}\text { Air danau tak } \\
\text { lagi jernih }\end{array}$ & $\begin{array}{l}\text { Tapi, among, } \\
\text { kau tetap } \\
\text { setia di sana }\end{array}$ & - & - & $\begin{array}{l}\text { Anak-anak muda } \\
\text { telah pergi }\end{array}$ \\
\hline 3 & - & $\begin{array}{l}\text { Bagai gelora } \\
\text { gadis cantik }\end{array}$ & - & - & $\begin{array}{l}\text { Berkejaran } \\
\text { menghantam } \\
\text { pinggir kaldera }\end{array}$ \\
\hline
\end{tabular}




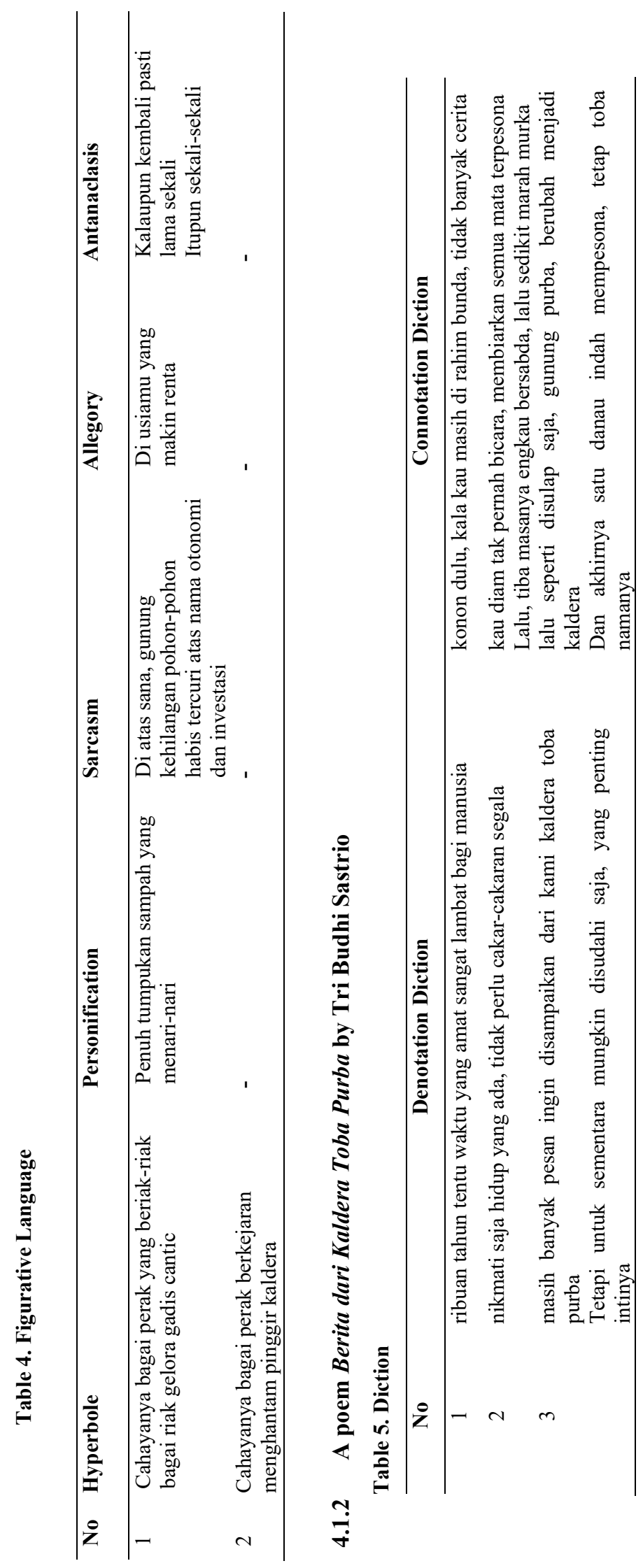




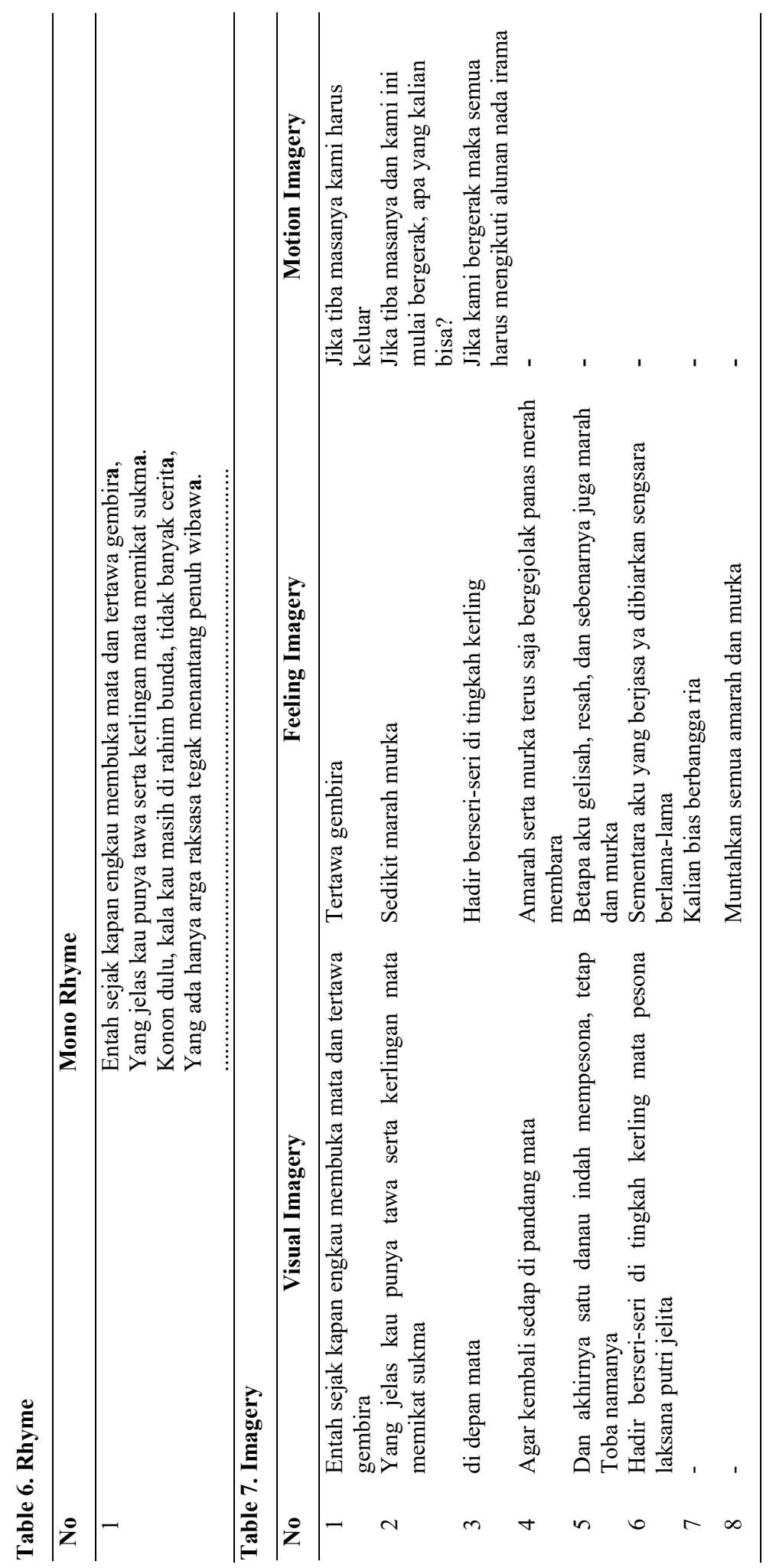




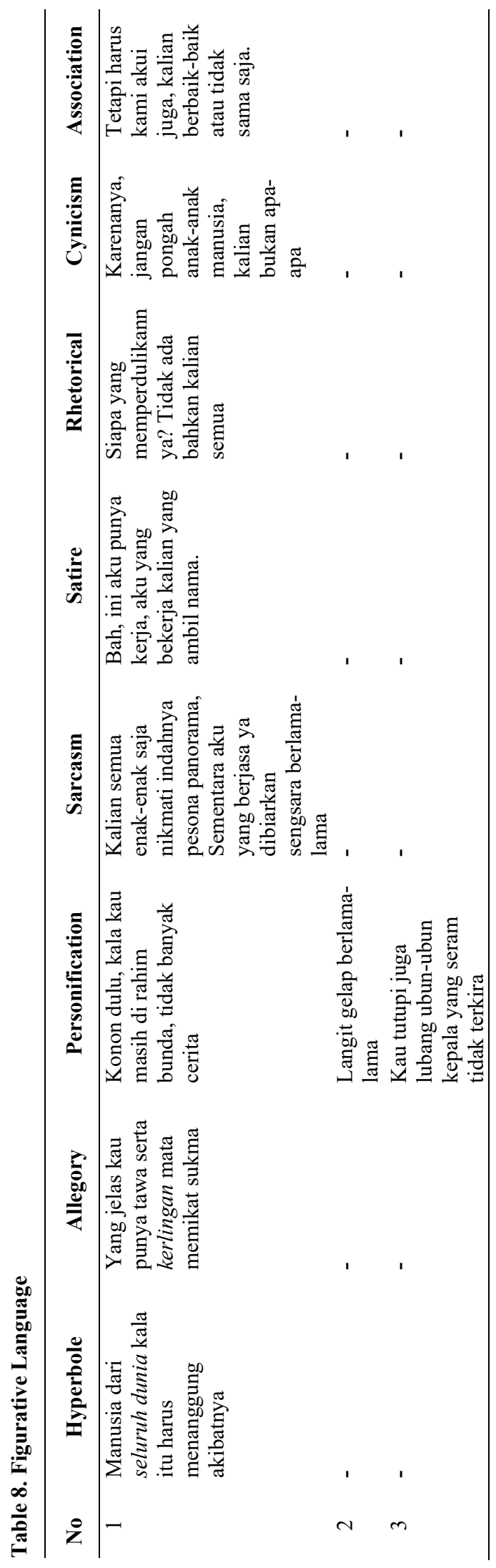




\subsection{Discussion}

\subsubsection{Perahu Kecil di Atas Danau Poem by Nestor Rico Tambunan}

\section{1) Diction}

The use of the right, careful, and correct diction can help give value to a word. The diction expressed in Perahu Kecil di Atas Danau poem has two meanings, those are denotation and connotation. At the beginning of the poem, the poet uses words that contain the true meaning occurred in the array aku menatapmu pagi itu, terayun-ayun di atas perahu kecil. The array is included in the meaning of the denotational word, because there are no words that contain figurative meaning. Furthermore, there is the connotation that adorns this poem. Connotation contains meaning that is not the actual meaning, but the figurative meaning or additional meanings. As seen in the second verse below, cahayanya bagai perak yang beriak-riak, bagai riak gelora gadis cantik

The array above is categorized in the connotation meaning because it uses the figurative word, thus producing meaning that illustrates the beauty of Lake Toba, sparkling like a beautiful girl.

\section{2) Rhyme}

The rhyme expressed in this poem created by Nestor Rico Tambunan using the a-a-b-b pattern or often called the clerihew rhyme that can be seen in the sixth stanza of the poetry, the excerpt is as follows,

$$
\begin{gathered}
\text { Di usiamu yang makin renta } \\
\text { mungkin teman, tanpa kekasih tercinta } \\
\text { kau tetap setia menjala pora-pora } \\
\text { karena kau tak mau berjudi } \\
\text { mencari hidup yang tak kau pahami } \\
\text { bahwa hidup tak melulu soal materi }
\end{gathered}
$$

The quote above has repeated vowels (a) and (i) on each line, indicating if the patterned rhyme is a-a-b-b which is commonly called clerihew rhyme. Next, in Perahu Kecil di Atas Danau poem there is also an alliteration rhyme which is the sound equation found in the initial sound of words on the same line, this rhyme is seen in the fourth line of the first verse of the poem.

\section{3) Imagery}

In the poem Perahu Kecil di Atas Danau by Nestor Rico Tambunan, the imagery contained in the poem can be seen here,

$$
\begin{gathered}
\text { Among, } \\
\text { aku menatapmu pagi itu } \\
\text { terayun-ayun di atas perahu kecil } \\
\text { menjala pora-pora } \\
\text { di antara riak dan kaldera }
\end{gathered}
$$

The first stanza on the second array, aku menatapmu pagi itu entered into the visual imagery. The poet creates a clear impression of sight by including the word menatapmu (staring at you). The visual condition that a child did to his father was in a boat on Lake Toba. Furthermore the visual imagery appears in the excerpt Banyak yang telah berubah air danau tak lagi jernih. The impression of observation is presented by the poet in his poem, the lake 
water that is no longer clear describes the condition of Lake Toba's water which is no longer clean and pure, many piles of garbage and waste water discharges at the tourist site.

Furthermore, in the array di antara riak dan kaledra included into the auditory imagery. This is evidenced by the impression of the sound of the water ripples created by the poet, so that the reader or connoisseur of the poem seems to see and hear the same thing. Other imageries occured in the Perahu Kecil di Atas Danau are feeling imagery, olfactory imagery, and motion imagery.

\section{4) Figurative Language}

In the Perahu Kecil di Atas Danau poem found several styles of language that adorn the poem. The language styles found are hyperbole, personification, sarcasm, allegory, and antanaclasis. The following are the excerpt of Perahu Kecil di Atas Danau which categorized as hyperbole,

$$
\begin{gathered}
\text { cahayanya bagai perak yang beriak-riak } \\
\text { bagai riak gelora gadis cantik }
\end{gathered}
$$

The sentence is said to be excessive because it already uses the word riak and then uses the word gelora and likens its beauty using two sentences namely perak and gadis cantik.

It was also found that personification was a style of language that seemed to replace the function of inanimate objects that could behave like humans. Found in the array "penuh tumpukan sampah yang menari-nari" in the array the author describes as if the garbage in Lake Toba can dance like humans. In the array of poems "di usiamu yang makin renta" in the array there is the figurative word which is the word "renta" which means aged or elderly, which can be categorized into allegory for comparing an object with the figure of speech. In addition to the figure of speech above, it is also found Sarcasm that can be seen in the the fifth line of third stanza "di atas sana, gunung kehilangan pohon-pohon habis tercuri atas nama otonomi dan investasi" on the array illustrates how the natural conditions that have experienced illegal logging due to the interests of a party.

Antanaclasis is also found in this poem, it occurs in the fourth stanza, fifth and sixth lines. Two words are the same, "sekali" but with different meanings. If on the fifth line means "membutuhkan waktu yang lama" on the sixth line means "jarang".

\subsubsection{Poetry Berita dari Kaldera Toba Purba by Tri Budhi Sastrio} 1) Diction

"Ribuan tahun tentu waktu yang amat sangat lambat bagi manusia,"

In the first line of the second stanza, the author uses denotative meaning that is the actual meaning or meaning that is following the understanding contained by the word and is also called general meaning. In this verse the poet illustrates that "Ribuan tahun" is a long time for humans, not only for humans but also for Kaldera Toba Purba. Hereafter, connotation meaning is also found in the poetry Berita dari Kaldera Toba Purba by Tri Budhi Sastrio, in the excerpt below,

"Konon dulu, kala kau masih di rahim bunda, tidak banyak cerita,"

The excerpt of the poem explains the phase of Lake Toba, which used to be a volcano that erupted and became a lake, on the poetry piece the writer explained that the mountain turned into a lake that seemed if humans are seen from the word "rahim". The word bunda means the mountain in the poem piece above. 


\section{2) Rhyme}

Rhyme contained in the poem above "Monorhyme" is the same vocal repetition found at the end of the rows of a poem. Seen from the whole array of poetry below:

Entah sejak kapan engkau membuka mata dan tertawa gembira,

Yang jelas kau punya tawa serta kerlingan mata memikat sukma.

Konon dulu, kala kau masih di rahim bunda, tidak banyak cerita,

Yang ada hanya arga raksasa tegak menantang penuh wibawa.

In the stanza above there is the same vowel repetition seen in the vowels (a-a-a-a) which recur on each line that indicates the monorhyme. The monorhyme presented by the poet makes it easy for the reader to understand the overall meaning that the poet describes the condition of Mount Toba which turns into an enchanting Kaldera.

\section{3) Imagery}

Poetry Berita dari Kaldera Toba Purba by Tri Budhi Sastrio tells the story of the news where the poet wants to convey from Lake Toba, there are three types of imagery found here. Firstly, visual imagery was found in the array "Entah sejak kapan engkau membuka mata dan tertawa gembira" sentence membuka mata is visual imagery that is described by poets using the eyes as imaginary poetry creation.

Then, in this poem some imagery found, one of them is the array of tertawa gembira can also be called "happy", but in the wholeness of the verse actually the poet conveying the eruption of Mount Toba which is now a beautiful and charming Kaldera Toba so Lake Toba became a tourist destination in North Sumatra. The last one is motion imagery, which found in the fifth stanza of this poem. Motion imagery is a depiction of objects that can abstractly move and concretely not move. In the temple imagery array found in the sentence Jika tiba masanya dan kami ini mulai bergerak, apa yang kalian bisa this array shows the action of Lake Toba as if it is threatening ad described by the poet of the word bergerak.

Motion imagery is also a depiction of objects that can abstractly move and concretely not move. In this seventh stanza, the motion imagery is found in the array "Jika kami bergerak maka semua harus mengikuti alunan nada irama" the word bergerak in the array indicates a movement that will occur. This illustrates the transfer from one place to another.

\section{4) Figurative Language}

Allegory found in the array "Yang jelas kau punya tawa serta kerlingan mata memikat sukma". The author, in this case, wants to say kedipan mata but decorate it with the figure of speech, which is kerlingan. Furthermore, the excerpt "Konon dulu, kala kau masih di rahim bunda, tidak banyak cerita" in the poetry, it is categorized as personification which is the style of language that seems to replace the function of inanimate objects that can behave like humans.

Furthermore, hyperbole occurs in the array "Manusia dari seluruh dunia kala itu harus menanggung akibatnya." In the sentence before, it can be seen that the author uses the word seluruh dunia, which could have been seluruh negara, but the author overestimates in explaining so it uses the word seluruh dunia. Sarcasm found in the array "Kalian semua enakenak saja nikmati indahnya pesona panorama. Sementara aku yang berjasa ya dibiarkan sengsara berlama-lama". The array is an expression of self-determination that is conveyed directly without imagery and stated strictly.

Another figure of speech found in the poem Berita dari Kaledra Toba Purba is satire, rhetoric, cynicism, and association. Satire found in the fourth line of the fifth stanza, meanwhile, rhetoric occurs in the array "Siapa yang memperdulikannya? Tidak ada bahkan 
kalian semua". Cynicism can be seen in the ninth line of the fifth stanza. The last one is association which can be found in the array "Tetapi harus kami akui juga, kalian berbaik-baik atau tidak sama saja".

\subsection{External Achievement}

The output achieved from the results of this study is the making of textbooks on Poetry Appreciation Courses which contains the concrete relationship between stylistics theories. Textbook entitled Stylistics of Poetry of North Sumatra Poetry will subsequently be used as material for researchers and students in conducting lectures in the Poetry Appreciation Course. In addition to making textbook-based teaching materials, the results of this study are also directed towards the creation of multimedia-based teaching materials especially audio-video integrated into the e-learning system of Universitas Negeri Medan FBS. The learning system in the blended learning form that has been implemented in FBS since the past two years makes it easier for researchers to publish the results of this multimedia-based research to students.

\section{Conclusion and Suggestions}

Based on the results of the research and analysis of the discussion, the five poems in the Anthology of Seribu Sajak Tao Toba Poems will be summarized in the following description. First, Perahu Kecil di Atas Danau poem by Nestor Rico Tambunan, based on the study of stylistics there are two types of dictions in the poem, they are the connotation and denotation diction. The style of rhymes found in this poem is the clerihew rhymes and alliterative rhymes, imagery found are visual, feelings, auditory, olfactory, and motion imagery, while the figurative language in the poem found in several types, there are hyperbole, personification, sarcasm, allegory, and antanaclasis. Secondly, Berita dari Kaldera Toba Purba poem by Tri Budhi Sastrio, based on a Stylistic study, there are two types of diction styles, namely connotation and denotation diction. The style of rhymes found in this poem is monorhyme. The imagery found in this poem is feeling, olfactory, visual, and motion imagery. The figurative language found in poetry is hyperbole, allegory, personification, sarcasm, satire, rhetoric, cynicism, and association.

The most common errors found in writing poetry that may be caused by editors are spelling mistakes, which involve punctuation, capital letters, italics, bold letters, etc. According to their function, the role of an editor is very huge for an author. On this good opportunity, the researcher advises on all types of writings / literary works to be published, the content should be repeatedly edited by several editors, so that the aesthetic impression on poetry can be conveyed and can be enjoyed by readers.

\section{References}

[1] Ratna, Nyoman Kutha. Stilistika Kajian Puitika Bahasa, Sastra, dan Budaya. Pustaka Pelajar, Yogyakarta. (2009).

[2] Daulay, Muhammad Anggie Januarsyah. Stilistika Menyimak Gaya Kebahasaan Sastra. Halaman Moeka Publishing, Jakarta. (2013) 
[3] Sudaryanto. Metode dan Aneka Tehnik Analisis Bahasa (Pengantar Penelitian Wahana Kebudayaan secara Linguistik). Duta Wacana University Press, Yogyakarta. (2003).

[4] Eli Syarifah Aeni, M.Hum. Edit-Linguistik Mahir Menyunting Naskah. Media Cendekia Muslim, Bandung. (2016).

[5] Keraf, G. Diksidan Gaya Bahasa. Ende Flores: Kanisius. (1981).

[6] Kamus Besar Bahasa Indonesia. Gramedia Pustaka Utama, Jakarta. (2011).

[7] Purba, Antilan. Stilistika Kaji Bahasa Karya Sastra. Fakultas Bahasa dan Seni Universitas Negeri Medan. Medan. (2005).

[8] Siahaan, Jhon Fawer. Seribu Sajak Tao Toba. CV. Mitra, Medan. (2014).

[9] Tarigan, H. Guntur. Prinsip-prinsip Dasar Sastra. Angkasa, Bandung. (2011). 